\title{
AS ESTRATÉGIAS DISCURSIVAS EM “A MORALISTA" DE DINAH SILVEIRA DE QUEIRÓS
}

\section{DISCURSIVE STRATEGIES IN “A MORALISTA" BY DINAH SILVEIRA DE QUEIRÓS}

SUELY LEITE ${ }^{1}$

RESUMO: O presente trabalho parte do pressuposto de que o texto de autoria feminina constrói, por meio de recursos enunciativos diferenciados, um discurso feminino. No conto "A moralista", escrito por Dinah Silveira de Queirós, é possível, através da linguagem, detectar a imagem e a representação de estereótipos femininos representados na literatura como forma de espelho da realidade, além de toda a ideologia que permeia a formação discursiva da qual esse discurso se originou. Também, como objetivos mais específicos, procura-se detectar o lugar do qual o sujeito enunciador constrói seu enunciado: lugar de repetição ou ruptura dos discursos circulantes na sociedade, e ainda mostrar como o sujeito histórico feminino formula seu discurso, trabalha a linguagem para produzir sentidos e construir sua identidade.

PALAVRAS-CHAVE: Análise do discurso; Discurso feminino; Conto; A moralista; Dinah Silveira de Queirós.

ABSTRACT: Thisworkseekstoprovethehypothesissurrounding

1 Docente da UEL - Universidade Estadual de Londrina. E-mail: celsul@uol.com.br. 
the way texts written by women, by means of differentiated enunciative resources, elaborates a discourse about women's universe. In the short story "A moralista" it is possible, through language, to detect the features of image and the stereotypes of women represented in literature as a mirror of the reality and also detecting the whole ideology that permeates the discursive formation which this discourse is originated from. Also, with more specific objectives, it tries to detect the place from where the subject, as enunciatee, constructs her utterance: a place for repetition or rupture of circulating discourses in society, and still shows how the historic subject of the enunciation formulates her discourse, deals with the language to produce meaning and constructs her identity.

KEYWORDS: Discourse analysis; Women's discourse; Short Stories; A moralista; Dinah Silveira de Queirós.

A Análise do Discurso (AD) de linha francesa, situada no campo das ciências da Linguagem, procura explicar a língua como um acontecimento social e surge por volta dos anos 60 do século XX, reunindo três áreas de conhecimentos: a Linguística, o Marxismo e a Psicanálise. Trata-se de uma disciplina que reivindica seu espaço de atuação com o objetivo de abordar as circunstâncias históricas do discurso, ao mesmo tempo em que procura encontrar, na materialidade do enunciado, marcas indicativas a respeito do processo de produção de um discurso no qual o enunciado terá sua forma determinada pelas possibilidades da língua e por elementos extralinguísticos; aspectos relevantes em um processo de enunciação. Campo de estudos muito difundido na França, a AD chegou ao Brasil e tem se tornado um campo muito fértil para a pesquisa.

Segundo a pesquisadora Eni Puccinelli Orlandi (2002, p. 15), “a Análise do Discurso concebe a linguagem como media- 
ção necessária entre o homem e a realidade natural e social"; portanto, a noção de discurso é vista enquanto efeito de sentidos entre locutores e estabelece uma relação entre a língua e os sujeitos que a falam, considerando os processos e as condições de produção da linguagem.

Mikhail Bakhtin (1979), entre outros teóricos, apresenta a concepção de linguagem enquanto meio de interação social, considerando a presença de um Outro na constituição do significado do discurso, desde a sua elaboração mental, passando pela materialização linguística e chegando ao momento da enunciação. Para o teórico russo, a enunciação vem a ser um elemento determinante na significação do discurso, um momento dialógico, pois recupera os já-ditos de outros discursos e os traz para a cena enunciativa, em posição de concordância ou discordância com eles. Atualmente, pesquisadores dos estudos discursivos consideram a língua como um acontecimento e tomam o enunciado como unidade de análise, passível de ser estudado em sua discursivização, na relação entre a matéria linguística e um sujeito afetado por uma formação discursiva, a história.

Articulando a materialidade linguística com o contexto social, a Análise do Discurso aproxima discurso e ideologia: o conceito de discurso formulado por Foucault (1969) e de ideologia formulado por Althusser (1974). Essas duas vertentes cruzam-se posteriormente em outro trabalho de fundamental importância para a AD, o de Pêcheux (1995), um dos teóricos que dará forma aos estudos discursivos ao elaborar conceitos inéditos acerca do discurso determinado e constituído por um tecido histórico-social.

Na concepção marxista, a ideologia é a maneira de a classe dominante ver o mundo e criar a ilusão de que não existem diferenças sociais entre dominantes e dominados. Essa elite 
propõe suas ideias como representantes de uma coletividade, escamoteando a realidade, apagando as contradições sociais, instaurando um discurso que legitima seu poder e se transforma em um mascaramento social. Althusser (1974) traz para os seus estudos essa ideia e propõe que a ideologia seja entendida como abstração e inversão da realidade e é nesse momento de oposição entre o real e o irreal que se instauram as lacunas, os brancos, os silêncios, os esquecimentos que garantem a manutenção da ideologia dominante que, por sua vez, é transmitida por aparelhos ideológicos do Estado, como a família, a escola, a religião, a cultura e outros. É nos discursos institucionalizados que a realidade é recortada intencionalmente, atenuando as contradições sociais. Marilena Chauí (1984) se afasta de Althusser em duas questões importantes: quanto à gênese da ideologia e quanto à existência da ideologia dos dominados. Althusser pensava na ideologia como "efeito" insuperável de qualquer tipo de estrutura social. Já Marilena Chauí percebe-a como um momento historicamente determinado em virtude da alienação, como produto da divisão do trabalho e da divisão da sociedade em classes. Althusser admite a existência da ideologia dos dominados, o que é refutado por Chauí, pois a filósofa considera que "falar em ideologia dos dominados é um contra senso, visto que a ideologia é um instrumento de dominação" (CHAUÍ, 1984, p. 115). Trata-se de uma discussão bastante controversa em que as ideias dos intelectuais mais conceituados não chegam a um consenso.

A AD, além da concepção de ideologia, tem como fundamento teórico a noção de discurso formulada por Foucault (1997). Para ele, os discursos são dispersos, não possuem uma unidade; porém, em sua dispersão, trazem uma regularidade que pode ser chamada de formação discursiva cuja composi- 
ção forma um conjunto com constituição regular, produzido por um sujeito que escolhe determinados signos para significar aquilo que quer dizer e o faz em um determinado momento, a partir de um lugar, constituindo-se assim a enunciação nos seguintes termos: espaço do dizer, condição material que faz com que o discurso seja concretizado.

Para Pêcheux (1995), o discurso configura-se no espaço das significações que são formuladas pelos efeitos de sentido. 0 discurso é produzido em determinadas condições, em um contexto histórico, a partir de uma formação ideológica. A junção desses elementos irá apontar para o efeito de sentido possível em um determinado discurso. Conhecendo o contexto histórico - a formação ideológica presente em um momento específico - o sujeito, ao produzir um discurso, assume um lugar e prevê a posição do Outro que recebe esse mesmo discurso, formulando estratégias para significar, para se fazer entender, para ideologicamente marcar sua posição frente a esse interlocutor e frente a outros discursos presentes na sociedade, recorrendo, assim, a formações discursivas para possibilitar os vários efeitos de sentido que ele possa ter. Enfim, a Análise do Discurso tem como objeto de estudo o dito, as escolhas do modo de dizer, as determinações históricas e sociais da produção do discurso, os lugares de onde são produzidos, os silenciamentos, esquecimentos e mascaramentos nas formas de dizer; o jogo, enfim, de associações e rejeições em relação a outros discursos.

$\mathrm{Na} A D$, o termo discurso tem sido definido como efeito de sentido entre locutores. Orlandi (2002) observa o sentido etimológico da palavra: ideia de curso, de percurso, de correr por, de movimento. Para a autora, por meio do estudo do discurso é possível observar o ser humano em sua prática de linguagem, pois este representa a palavra em movimento, pro- 
cessos nos quais os sujeitos se inserem. Portanto, sua origem não está no sujeito que o produz, mas sim na relação com outros dizeres já-ditos, imaginados ou possíveis de serem ditos.

Concordando com Eni Orlandi (2002), o pesquisador Sírio Possenti (2001, p. 64) postula o entendimento do termo discurso como "colocação em funcionamento de recursos expressivos de uma língua com certa finalidade, atividade que sempre se dá numa instância concreta entre um locutor e um alocutário", acrescentando que o discurso não é uma simples transmissão de informações, mas um processo de constituição de sujeitos que produz sentidos afetados tanto pela história como pela língua, esta última representando uma das condições que possibilitam a prática do discurso.

O discurso significa, produz algum efeito, representa um acontecimento, expressa posições de classe ou grupo, por isso, é ideológico. E como acontecimento, envolve uma relação entre um eu e um tu que negociam, constroem e produzem efeitos de sentido. Esse acontecimento nunca se dá de forma original, pois sempre tem sua formulação baseada em outro discurso, com o qual dialoga explícita ou implicitamente. Já para Foucault (1997), significa uma prática que tem sua origem na formação dos saberes, podendo ser ainda um jogo estratégico e polêmico, espaço de articulação entre saber e poder. Trata-se, enfim, de uma prática discursiva que pode ser determinada por procedimentos externos ou internos que marcam o lugar do sujeito que fala. Todo indivíduo constitui o lugar de formas conflitantes de subjetividade, assumindo posições discursivas dentro de sistemas de sentidos e valores. No discurso, a subjetividade discursiva representa a cena de batalha pelo poder, pois é lugar de repetição ou resistência ao já-dito, ao já-institucionalizado, ao discurso cristalizado, à ideologia dominante. 
O sujeito, para construir seu discurso, se vale dos já-ditos ao dispor de um conjunto de signos produzidos pela sociedade em várias situações de interação e em vários lugares sociais. É reiterando signos conhecidos e organizando-os em um novo espaço e em uma nova situação de comunicação que o sujeito deixa marcas de seu posicionamento, seu ponto de vista, seu modo de ver o mundo e sua forma de dialogar com os já-ditos pela sociedade. Assim, por meio da materialidade linguística, pode-se observar como o sujeito produz seu discurso dividindo o espaço discursivo com o Outro, com vozes que revelam o comprometimento ou não do enunciador com o discurso que formula. Para Pêcheux (1995), uma determinada palavra ou expressão tem o seu sentido determinado pelo processo social e histórico no momento de sua produção. Para Orlandi (2002), o discurso materializa-se especificamente na ideologia, sendo possível, por meio dele, a compreensão de como a língua produz sentidos a partir de e para os sujeitos, pois não existe sujeito sem ideologia.

Althusser (1974), por sua vez, percebe a ideologia como um sistema de representações imaginárias que os indivíduos fazem de suas condições reais de existência social. A ideologia existe através do sujeito e para sujeitos que, em uma determinada sociedade, possuem um sistema de ideias, de representações sociais que englobam a prática política, jurídica, moral, religiosa, estética, filosófica, não sendo representações objetivas do mundo, mas de elementos imaginários. Os homens interagem sob a égide de uma ideologia; é ela que lhes forma e conforma a consciência, amoldando-a às condições de existência real do ser humano, pensamento também presente nos estudos de Orlandi (2002, p. 46), para quem "a ideologia é a condição para a constituição do sujeito".

A ideologia fornece aos sujeitos de uma dada formação 
social uma certa homogeneidade nos modos de interpretar o mundo. Porém, em uma sociedade de classes, é a ideologia dominante que nomeia e busca levar os sujeitos à conformação para que o sistema seja garantido na sua reprodução e preservação. A ideologia mascara a realidade, homogeneizando os indivíduos aos lugares-comuns, clichês e discursos cristalizados que se materializam por meio da palavra.

Todo discurso é a manifestação da ideologia de um sujeito que opta por formular o que quer dizer e como dizer, mas segundo determinadas condições:

[...] dizer que o falante constitui o discurso significa dizer que ele, submetendo-se ao que é determinado (certos elementos sintáticos e semânticos, certos valores sociais) no momento em que fala, considerando a situação em que fala e tendo em vista os efeitos que quer produzir, escolhe, entre os recursos alternativos que o trabalho linguístico de outros falantes e o seu próprio, até o momento, lhe põem à disposição, aqueles que lhe pareçam os mais adequados (POSSENTI, 2001, p. 77).

Dialogando com Althusser e com Eni Orlandi, Sírio Possenti traz para a discussão a noção de um sujeito preso a convenções linguísticas, porém com certa autonomia para escolher, dentre um leque de opções, aquelas que mais lhe favoreçam na formulação de seu discurso. Essa noção de um sujeito assujeitado está presente nos estudos de Dominique Maingueneau (2002) que, em prefácio à obra intitulada Os limites do discurso (apud POSSENTI, 2002, p. 11), designa o termo sujeito como um indivíduo assujeitado a algum poder absoluto mas, ao mesmo tempo, contestador desse poder e assumindo-se como sujeito de pleno direito. Esse sujeito é simbólico, está atado à linguagem presente na história para significar, seja na constituição, seja na formulação ou na circulação do discurso que produz. 
Ao interpretar, influenciado pelo modo de funcionamento da linguagem, o sujeito submete-se à ideologia, apagando ou evidenciando sentidos na materialidade linguística e histórica, trazendo o já-dito para o discurso; enfim, é pela interpretação que o sujeito significa e faz significar. Na instauração do dizer, o sujeito joga com as diferentes formações discursivas trazendo ou escondendo a relação que tem com outros discursos, com o Outro, e são esses procedimentos discursivos que determinam o lugar da ideologia, da historicidade, da interpretação. 0 discurso traz as marcas da articulação entre língua e história, sujeito e ideologia, pois "não há discurso sem sujeito e não há sujeito sem ideologia. Há, entre os diferentes modos de produção social, um modo específico que é o simbólico. Há, pois, práticas simbólicas significando (produzindo) o social" (ORLANDI, 2001, p. 63).

Para Bakhtin (1979), a linguagem representa o lugar privilegiado para a manifestação da ideologia, pois cada enunciação pode retratar pontos de vistas diversos, ser lugar de embate de várias vozes, porque é na articulação entre o que se quer representar e o signo escolhido para isso que a ideologia se revela.

A noção de sujeito em $\mathrm{AD}$ acaba reiterando um outro fenômeno discursivo: a subjetividade. 0 sujeito ambíguo, devido a suas contradições, interpelado por uma ideologia, colocase como dono de suas palavras e de seu discurso, precisando, porém, sujeitar-se ao código escrito, a um sistema linguístico; o que o torna, contraditoriamente, um sujeito assujeitado e ao mesmo tempo dono de uma subjetividade livre porque ocupa um lugar de onde fala:

Ao dizer, o sujeito significa em condições determinadas, impelido, de um lado, pela língua e, de outro, pelo mundo, pela sua experiência, por fatos que reclamam sentidos, e também 
por sua memória discursiva, por um saber/poder/dever dizer, em que os fatos fazem sentido por se inscreverem em formações discursivas que representam no discurso as injunções ideológicas (ORLANDI, 2002, p. 53).

Eni Orlandi (2002), ao discutir a noção de um sujeito marcado ideologicamente, traz para a discussão o conceito de autoria de um discurso. Para a pesquisadora, um sujeito é marcado por contradições, pelo já-dito, pela ilusão de ser autor de seu discurso, pelos vários papéis que pode assumir em uma formação discursiva; sujeito este ideológico que se permite acreditar ser a fonte de seu discurso, porém preso às formações discursivas às quais pertence, às formações ideológicas de seu tempo, de seu espaço; preso, enfim, às vozes que lutam em seu interior, sem poder controlar os efeitos de sentido que seu discurso possa suscitar. Segundo Orlandi (2002, p. 47), a ideologia define o sentido de um discurso na sua relação com a língua e com a história.

Para Possenti (2001), o sujeito constitui um discurso à medida que, no momento da materialização discursiva, ele submete-se ao que já está determinado, como por exemplo, certos elementos sintáticos e semânticos, certos valores sociais, tendo em vista a situação de comunicação na qual interage e os efeitos de sentido que quer produzir; portanto, embora dentro de um universo pré-determinado, o sujeito é capaz de fazer as escolhas que lhe pareçam mais adequadas. Se por um lado ele é assujeitado, por outro, é sujeito que administra suas próprias opções; porém, uma vez materializado seu discurso, o sujeito já não tem mais poder sobre ele. Para Orlandi (2002), o sujeito é assujeitado à língua e à história, já que sem esses dois elementos, ele não se constitui, não produz sentidos. 0 sujeito é sujeito de e sujeito a: "é um sujeito livre e ao mesmo tempo submisso. Ele é capaz de uma liberda- 
de sem limites e uma submissão sem falhas: pode tudo dizer, contanto que se submeta à língua para sabê-la" (ORLANDI, 2002, p. 50).

Determinado pelo inconsciente e perdido na linguagem, o homem deixa de ser o centro e a medida de todas as coisas. Em lugar de um sujeito unificado e coerente, senhor de uma consciência livre, tem-se aquele que se torna apenas uma construção da linguagem, não podendo ser considerado a origem do sentido, do conhecimento, da ação. Assim, não se pode pensar em um sujeito como indivíduo, pois ele se acha fragmentado por uma alteridade que o habita e que não consegue conhecer totalmente e nem controlar, pois o eu é efeito de outros discursos incorporados através de contatos e relações. Neste sentido, o discurso produzido configura-se em um espaço internamente marcado pela diferença, pela heterogeneidade, por lugares culturais e ideológicos tensos, afetados por várias formações discursivas.

Conceitos difundidos pelo pensamento de Foucault (1997) definem formação discursiva como um conjunto de enunciados, unidades básicas que formam um discurso, marcado pelas mesmas regras de formação. 0 que une textos de uma mesma formação discursiva é um complexo feixe de ideias e atitudes regidas pelo modo como as relações sociais acontecem na história e, consequentemente, são regidas por uma ideologia dominante. As formações discursivas caracterizam as condições de aparição do discurso enquanto prática. O sentido dado por elas torna-se o lugar de interpretações, espaço da enunciação, reduto de porta-vozes, referencial de formações ideológicas que determinam o sentido do discurso produzido.

A formação discursiva, segundo Foucault (1997), pode ser entendida como um conjunto de acontecimentos enuncia- 
tivos, uma rede retórica, um campo de possibilidades estratégicas, cujos elementos são regidos por determinadas regras de formação e produzidos em um determinado momento e em uma determinada sociedade. A formação discursiva estabelece um ethos ou um modo de dizer; determina o que deve ser dito e de que forma dizê-lo em um determinado grupo.

O sentido de um discurso não existe em si, uma vez que é determinado por posições ideológicas e sócio-históricas evocadas no momento de sua produção, que determinam aquilo que pode e deve ser dito em suas redes de significação, consideradas pela AD como condições de produção.

Se todo discurso torna-se determinado por algumas condições que geralmente estão relacionadas ao contexto social em que é produzido, para Orlandi (2002), elas compreendem os sujeitos, a situação e a memória. Em um sentido bem restrito, as condições de produção podem ser entendidas como o contexto imediato, circunstâncias da enunciação. Em um sentido mais amplo, já incluem o contexto sócio-histórico e ideológico, pois o sujeito é um ser social e o seu discurso reflete sua situação socioeconômica e também sua posição ideológica. Ainda segundo a teórica (ORLANDI, 1993, p. 17), "tomar a palavra é um ato social com todas as suas implicações: conflitos, reconhecimentos, relações de poder, constituição de identidades". Essa tomada de palavra inclui um percurso que passa pelo psíquico, pelo social e pela ideologia. As condições de produção englobam a materialidade do discurso, que é a língua, a formação social do sujeito que produz esse discurso e o mecanismo imaginário, fazendo com que seja reconhecido e adquira sentidos.

Reconhecer um discurso é ater-se às circunstâncias de sua enunciação, ao seu contexto sócio-histórico, à sua memória discursiva e ao seu modo de circulação. A relação entre to- 
dos estes elementos constitui-se no que a AD denomina condições de produção, ou ainda, formulação discursiva:

Formular é dar corpo aos sentidos. E, por ser um ser simbólico, o homem constituindo-se em sujeito pela e na linguagem, que se inscreve na história para significar, tem seu corpo atado ao corpo dos sentidos. Sujeito e sentido constituindo-se ao mesmo tempo têm sua materialidade articulada na materialidade da língua com a materialidade da história (ORLANDI, 2001, p. 9).

A formulação discursiva refere-se ao momento em que o sujeito diz o que diz. É o acontecimento discursivo em que há a manifestação do sujeito, e esse momento se materializa pela textualização do discurso, situação em que as palavras ganham sentidos, em que ocorre a atualização da memória, momento em que o sujeito se revela ou se esconde.

0 texto, segundo Orlandi (2001), explica como o sujeito, a partir de suas condições, pratica a relação do mundo com o simbólico, ou seja, como ele materializa sentidos, formula sua discursividade, revela sua ideologia. Ele representa um objeto simbólico que produz sentido, constituído por processos de significação, heterogêneo do ponto de vista de sua constituição discursiva: ele é atravessado por diferentes formações discursivas, afetado por diferentes posições do sujeito, em sua relação desigual e contraditória com os sentidos, com o político, com a ideologia. 0 texto, manifestação concreta do discurso e unidade imaginária, faz refletir a sua formulação ideológica, faz-se interpretar, significa o sujeito. A teórica ainda o define como prática discursiva que se configura em uma réplica do diálogo social, apresentando-se como retrato de uma realidade em que são registradas as instâncias ativas do processo social num determinado momento histórico, são 
fatos de linguagem, possuem uma natureza linguístico-histórica e concretizam uma rede de relações significativas:

O texto [...] é a unidade de análise afetada pelas condições de produção e é também o lugar da relação com a representação da linguagem: som, letra, espaço, dimensão direcionada, tamanho. Mas é também, e sobretudo, espaço significante: lugar de jogos de sentidos, de trabalho da linguagem, de funcionamento da discursividade (ORLANDI, 2002, p. 72).

Ao escolher, dentro dos meios formais da linguagem, uma maneira de concretizar seu discurso, o sujeito o faz dentro de um contexto social, rege-se por um sistema linguístico e manifesta as várias formações discursivas que constituem o seu discurso. 0 texto, lugar da significação desse sistema linguístico, produto de uma formação ideológica, torna-se dialógico porque nele está inserida a presença de outros interlocutores e de outros textos. Para a estudiosa do discurso Maria do Rosário Gregolin (2001, p. 65), “todo texto é composto por palavras que um 'eu' retoma de um 'outro'”, pois é a organização de outros discursos, nos quais a presença do Outro articula-se em uma relação com um saber, com um já-dito, e essa retomada discursiva acumula novos sentidos que podem ser de deslocamento, de acréscimo, de negação em relação ao discurso retomado.

0 texto torna-se manifestação concreta do discurso pelo qual se tem acesso à discursividade de um trajeto, de um pedaço no qual se configura um discurso formulado; lugar de entrada no modo como o sujeito constitui-se no sentido e na história. 0 discurso é fruto de uma determinada formação ideológica, materialização de uma ideologia, que dá suporte aos vários textos que circulam em uma sociedade para que esses sejam passíveis de interpretação, de interação. Todo discurso 
diz-se político porque simboliza as relações de poder que se materializam no texto, espaço de manifestação do enunciado, no qual existe a voz de um sujeito que enuncia algo e o faz de forma cultural, social e ideologicamente marcada.

Gregolin (2001) mantém um diálogo com as ideias de Orlandi e acrescenta que todo texto está organizado em torno de uma rede de memória e representa um trabalho de composição do novo a partir da repetição de um já-dito, aprisionando os vários sentidos em uma única forma textual. Tal procedimento forma uma rota que indica outros lugares para os discursos retomados, pois o sentido está no processo discursivo que se constitui em um jogo em que estão presentes o sujeito, o texto, a história e a busca de sentidos. Orlandi (2002), por sua vez, considera o texto como fato linguístico que apresenta diferentes processos de significação, que possui uma materialidade histórica, uma trama de sentidos, uma unidade significante complexa que organiza a relação do sujeito com o mundo.

Os recursos enunciativos usados na construção de um texto revelam o discurso ali representado e é por meio dele que se pode ter acesso a um discurso. Segundo Orlandi (2002), o texto é uma unidade determinada pelas condições de produção e lugar da relação com a representação da linguagem, constituindo-se como uma das peças de linguagem de um processo discursivo, um exemplar do discurso, enfim, um retrato da relação do sujeito com o mundo à sua volta.

Todo discurso é produzido por um sujeito e todo texto por um autor. $\mathrm{O}$ sujeito do discurso é interpelado pela ideologia e o autor é a representação desse sujeito cumprindo uma função discursiva. No discurso, o sujeito é opaco; no texto, o autor deve ser visível, coerente e fazer com que seu texto apresente um percurso capaz de representar um discurso. Segundo Gregolin (2001) o texto é apenas uma simulação da 
evidência e da completude de sentido, uma rota que indica outros lugares para a interpretação, e nele há a impossibilidade de se encontrar a origem do sentido, pois esta não está no sujeito, nem no texto. 0 sentido reside no processo discursivo, é um jogo, uma busca de interpretação em que estão presentes o sujeito, o texto e a história.

Todos os textos favorecem de alguma maneira as descobertas de sentidos. 0 texto literário, porém, estabelece trocas comunicativas, torna-se o resultado de uma interação criadora e receptiva que exige uma participação ativa do leitor na construção de sentidos. As obras literárias apresentam um leque de possibilidades de interpretação, evidenciam um discurso que oferece vários planos de leitura, tornando-se um espaço de representações coletivas. Opinião comum entre muitos pesquisadores da relação entre leitura e sociedade, como Marisa Lajolo e Antônio Cândido.

A literatura, segundo Cândido (1995, p. 243) representa um fator indispensável de humanização, porque confirma o homem na sua humanidade, atua no subconsciente e no inconsciente, tem sido poderoso instrumento de instrução e educação. Confirma e nega, propõe e denuncia, apoia e combate, coloca os problemas de forma dialética. Essa ideia também é corroborada por Marisa Lajolo (1997), para quem a literatura é, ao mesmo tempo, radar e espelho da sociedade:

[...] a relação entre a sociedade e a literatura, além de exprimir-se nas representações do social presentes no texto literário, não se esgota nisso: expressa-se também nas diferentes formatações do aparelho cultural necessário à prescrição de certas representações simbólicas e à proscrição de outras, através de instituições nas quais se produzem, legitimam e põem em circulação os discursos legitimadores das diferentes representações simbólicas (LAJOLO, 1997, p. 64). 
Os textos literários não necessitam apontar para o real, porém os processos sócio-históricos estão representados pela linguagem literária, pela forma como o homem pensa o mundo, e essas formas envolvem lacunas que podem ser preenchidas no ato da enunciação. A riqueza polissêmica da literatura faz com que o enunciatário mobilize sua memória e formulação discursiva, levando-o a participar ativamente da construção de sentidos.

Para o professor Francisco Paulo da Silva (2001), a materialização linguística de um discurso só é possível por meio de algum gênero que desempenha um importante papel na construção de sentidos, não só por seus traços formais como também pela sua função sócio-comunicativa: "A escolha de um gênero por um sujeito é uma das formas que ele encontra para produzir sentido quando se inscreve em atividades comunicativas, o que caracteriza o gênero como uma prática discursiva" (SILVA, 2001, p. 192).

Ao movimentar-se em um determinado gênero, o sujeito está em busca dos efeitos de sentido, dando o tom, instaurando-se no discurso, motivando respostas que constituirão outros discursos que dialogam com o seu.

Retomando Silva (2001) quando considera que a escolha de um gênero desempenha um papel importante na construção de sentidos, cabe aqui um breve comentário sobre a escolha do gênero conto para compor o corpus desse trabalho, por funcionar como uma fotografia de uma realidade sintetizada, como registro de um flagrante da vida, como pequenos caminhos que conduzem a uma travessia.

0 conto é um fragmento da realidade que visa ir além de suas limitadas páginas, apresentando a ideia de impacto, condensação de espaço e tempo; conteúdo aparentemente banal, mas que se torna excepcional devido a sua intensidade 
e tensão interna. Segundo Alfredo Bosi (1994, p. 9), em seus estudos sobre a situação e formas do conto brasileiro contemporâneo, "o contista é um pescador de momentos singulares cheios de significação". Define-se usualmente o conto como a narrativa que oferece uma amostra da vida, por meio de um episódio, um flagrante ou instantâneo, um momento singular e representativo. Constitui-se de uma história curta, simples, com economia de meios, concentração da ação, do tempo e do espaço. Muitas podem ser as formas do conto: policial, de mistério, de suspense, de ficção científica; conto rural (da geração modernista), alegórico (literatura do absurdo), psicológico (com monólogo interior, solilóquio, preocupação insistente com a personagem, com sua posição diante do mundo), picaresco, de costumes. Além do conto com presença de realismo fantástico, há também o conto de atmosfera; neste, a personagem encontra-se disposta em uma situação bastante cotidiana, havendo, em torno desta cotidianidade, a preparação de um incidente ou de um evento pressentido apenas discretamente. Após o evento ou o incidente que ilumina a vida da personagem, presencia-se um desfecho em que se considera sua situação posterior.

A fragmentação, geralmente relacionada com os limites de extensão do gênero, é também uma forma intencional de se lidar com os fragmentos da vida, de tal maneira que os resultados não seriam os mesmos dentro de uma narrativa baseada em sequência e/ou integralidade. 0 próprio ato de recortar é uma escolha carregada de significação. Segundo Gotlib (1998, p. 67) devido à sua forma de construção, os contos "tendem a causar uma unidade de efeito, a flagrar momentos especiais da vida, favorecendo a simetria no uso do repertório dos seus materiais de composição". O conto pode ser visto como uma história que não tem fim; é o recorte que não revela, mas su- 
gere, surpreende com o flagrante da alma humana, por isso comove, ensina. Essas características contribuíram de forma decisiva para a escolha do corpus deste trabalho por se tratar de um gênero em que se podem encontrar, de forma reveladora ou sugestiva, a representação feminina e as estratégias discursivas. Esses elementos estão presentes no conto "A moralista" de autoria de Dinah Silveira de Queirós escrito em 1948 e que, além de várias outras publicações, consta na seleção de Gasparino Damata intitulada Histórias do Amor Maldito, pela Gráfica Record Editora, em 1967. Para esse artigo será usado o texto que consta da coletânea Os cem melhores contos brasileiros do século, de Ítalo Moriconi, publicado em 2001 pela editora Objetiva.

O conto, escrito em 1948, repercute um discurso no qual os papéis definidos para homens e mulheres eram muito bem demarcados: ao homem, a esfera pública, e à mulher, o espaço privado.

O conto "A moralista" escrito em primeira pessoa vai além dessa demarcação. 0 discurso presente na narrativa constitui-se no registro da filha acerca do comportamento feminino da mãe que atende aos padrões de comportamento social permitidos à mulher e dela esperados. Como prisioneira das representações tradicionais femininas, vive um jogo de aparências em que o seu atributo de "a moralista" é o que rege não apenas sua vida, mas a de todos os habitantes da pequena cidade de Laterra. 0 discurso da narradora revela a célula familiar centralizada na figura de uma mulher, esposa e mãe, que assume a condição de ser representante do papel que a sociedade espera que ela cumpra, e sua trajetória é registrada pelos olhos de sua jovem filha, que começa a construir a figura materna a partir da esfera familiar. Em casa, no espaço reservado à família, a mãe dava risadas, arrumava-se para o 
jantar, perfumava-se, trajava vestidos alegres, decotados, porém não se pintava, não escondia sua face, não usava máscara. A mãe ocupava o posto de rainha do lar e era assim pelo marido tratada. A narradora afirma que o pai adulava a mãe como se dela dependesse, tratando-se apenas de uma forma de agradar sua eterna menina, assim chamada pelo marido. Depois de conversar com uma espírita, a mãe passa a aconselhar as pessoas da pequena cidade em tudo o que iriam fazer. Seus conselhos nunca falham, e ela passa a entender de política, negócios, casamentos tornando-se, assim, a figura central daquela pequena cidade. Seu prestígio (advindo de sua sensatez) faz com que o marido tenha orgulho de desfrutar da companhia de alguém com tanta sabedoria e ele, então, acaba se beneficiando em seus negócios por meio do reconhecimento social da esposa.

0 prestígio moral da mulher atinge os domínios da igreja quando passa a fazer as novenas e a rezar os terços, em função da ausência de um padre na cidade, chegando a ser conhecida como "padra". Para tanto, veste-se de forma que sua imagem se associe a uma figura sagrada, passando a ser vista pelos habitantes da pequena cidade como uma santa. Ao olhar da jovem filha, uma constatação: santa não poderia ser, pois, no refúgio do lar, a mãe se divertia, e uma santa, no discurso cristalizado e absorvido pela narradora, jamais daria as risadas como as que ela ouvia sair da boca da mãe.

A mãe incorporara seus atributos de conselheira e atribuía a si o adjetivo de pessoa equilibrada, caridosa, líder de uma cidade. Funda, assim, o Círculo dos Pais de Laterra e, a cada dia que passa, sua credibilidade cresce. Porém, aos olhos da filha, o discurso da mãe nada mais significava que uma representação social.

O equilíbrio aparente da família e da imagem da mora- 
lista perante a cidade é quebrado com a chegada de um rapaz que "parecia uma moça bonita". A mulher pede ao marido que lhe dê um emprego, para que este possa estar próximo de uma família, pois acredita que, com seus conselhos, repreensões e exemplos, ela conseguirá o seu propósito: curar o moço. 0 pai é advertido de que o rapaz não é o tipo de gente que deva morar em casa de respeito, mas a mãe sabe o que faz, portanto, o hóspede passa a frequentar a casa diariamente.

O comportamento afeminado do rapaz é censurado pela mulher, pois, ao mesmo tempo em que lhe repreendia, falavalhe palavras de ternura e otimismo, o que fez com que o rapaz se aproximasse mais daquela família e, em pouco tempo, deixara de ser um estranho. Sua convivência com as práticas religiosas da família o tornara assíduo aos terços, sua timidez diminuiu, seus gestos afeminados foram ficando para trás e suas atitudes deixaram de ser ridículas aos olhos dos outros. E toda essa transformação devido à companhia e ensinamento daquela que era considerada o esteio moral da pequena Laterra.

Entretanto, os discursos da mulher dirigidos àquela comunidade perdem a força e, os olhares da comunidade dirigidos ao rapaz, quando em companhia de sua protetora, são maliciosos. A filha capta essa malícia e frustra toda a expectativa sobre a façanha que a mãe alcançara ao fazer do moço um rapaz de comportamento masculino. 0 pai, embora cônscio da seriedade da esposa, se entristece por ter de conviver com aquela situação: ter em sua casa aquele que era alvo dos comentários de adultério da esposa. A narradora faz emergirem suspeitas sobre a conduta da mãe e essas suspeitas são reveladoras dos códigos que regiam a vivência entre as pessoas daquela comunidade. $\mathrm{O}$ entrelaçamento dessas suspeitas indica quão tênue era a linha que separava as alianças e os conflitos em torno da moralista. 
A moralista foi a última pessoa que percebeu a paixão que havia despertado no rapaz. Diante da insistência do marido, a mulher argumenta que é preciso mais tempo para fazer do moço um homem de bem e ele aceita. 0 rapaz, já muito à vontade, conta histórias que levam a moralista aos risos, deixa-a à vontade e, em um desses momentos, vislumbra o pescoço descoberto da mulher e a encara com os olhos vibrantes. Após adoecer, a moralista o visita e o moço lhe confessa algo. Diante de tal revelação, a mulher fica furiosa e, desencantada, pede ao marido que mande o rapaz embora. 0 moço volta para a reza e ela lhe ordena que saia daquele local. A renúncia pública da mulher à companhia do rapaz traz o alívio a todos da cidade e as pessoas voltam a acompanhar a moralista em seu terço, desta vez com vozes mais firmes que outrora. A expulsão do rapaz comprova a ideia geral de restauração de valores autoritários que perduram. Passados alguns dias, um fazendeiro o encontra enforcado junto a uma mangueira e aquela cena trágica era a prova de que a cidade precisava: "sua senhora não transigira, sua moralista não falhara" (QUEIRÓS, apud MORICONI, 2001, p. 184). A cidade respira aliviada. A moralista retoma sua vida, segue a risca os padrões sociais de seriedade: já não sorri, usa vestidos pretos, cerrados no pescoço, volta ao equilíbrio inicial, porém, seus conselhos já não são tão convictos como antes.

O discurso presente no conto "A moralista" propõe, de forma sutil, um novo modelo de atuação da mulher em direção ao social, embora essa incursão em direção ao Outro tenha deixado marcas na conduta da protagonista. A representação masculina também supera as delimitações tradicionais da época; superação esta encarnada nas duas personagens masculinas da trama narrativa em questão: uma, o marido da protagonista, lida melhor com as tensões do mundo, mostra-se de forma 
conciliadora, desvencilha-se das pressões sociais em busca da harmonia familiar, sua convivência no lar é marcada por admiração e demonstrações de carinho. Tem-se, no conto, um discurso que registra a mudança no modelo do pai na família em meados do século XX, mudança reiterada por Rocha-Coutinho (1994, p. 91), quando o pai deixava de ser simplesmente o provedor econômico da família para ser aquele que devia zelar pela felicidade e bem-estar de sua esposa e filhos. "Nesta nova função de pai - o pai amoroso e atento aos seus -, o homem deveria encontrar sua mais alta realização humana". 0 segundo, o hóspede da casa da protagonista, fugindo ao padrão de masculinidade, apresenta-se inseguro e fragilizado, incapaz de enfrentar as dificuldades da vida com firmeza e apresenta traços de homossexualidade. A imagem masculina imposta pela ordem patriarcal começa a ser desconstruída neste conto, na retratação desses dois personagens.

Sabemos que, na maioria das sociedades, os homens detiveram alguma autoridade sobre as mulheres. Entretanto, muitas das vezes, e não de forma reconhecida, certamente as mulheres influenciaram a vida social dos grupos a que pertenceram. No conto de Dinah Silveira de Queirós a autoridade masculina é minimizada pelo fato de a protagonista ter encontrado uma maneira de exercer a sua autoridade. Segundo Rocha-Coutinho (1994, p. 20), "poder e autoridade são conceitos que caracterizam, entre outras coisas, as formas de sujeição e os meios através dos quais as decisões são tomadas e executadas". Assim, pode-se dizer que em "A moralista", o poder e autoridade são exercidos por uma mulher que, através de estratégias de controle, leva uma comunidade a pensar, sentir ou agir de um modo diferente, atributos já prenunciados pela espírita que a aconselhou: 
[...] procure impressionar o próximo. A senhora tem um poder extraordinário sobre os outros, mas não sabe. Deve aconselhar... Porque... se impõe, logo à primeira vista. Aconselhe. Seus conselhos não falharão nunca. [...] Consultavam mamãe a respeito de política, dos casamentos. Como tudo que dizia era sensato, dava certo, começaram a mandar-lhe também pessoas transviadas (QUEIRÓS, apud MORICONI, 2001, p. 180).

A família retratada no conto "A moralista" apresenta mudanças, avanços em termos das relações afetivas dos papéis desempenhados por seus membros constitutivos. A mulher é aquela que detém a autoridade sobre sua casa, filhos e família e que, indo além, exerce uma influência no espaço público, tem consciência de seu papel político: "nunca fui uma fanática, uma louca. Sou, justamente, a pessoa equilibrada, que quer ajudar o próximo". O papel social que passa a exercer é forte o suficiente para que ela possa influenciar na imagem e nos negócios do marido, que fica encantado com o prestígio de ser o marido da moralista: "sentiu afluir a confiança que se espraiava até seus domínios” (QUEIRÓS, apud MORICONI, 2001, p. 182), apresentando claramente uma inversão dos papéis sociais.

Na historiografia ocidental, com o advento e hegemonia do discurso cristão, a mulher se viu representada a partir de duas figuras antagônicas em suas representações: Eva vs. Maria. Essa dualidade, no conto, dá-se pelo olhar que a filha dirige à mãe: "se me falam em virtude, em moralidade ou imoralidade, em condutas, enfim, em tudo que se relacione com o bem e o mal, eu vejo Mamãe em minha ideia" (QUEIRÓS, apud MORICONI, 2001, p. 180). Para a representação de Eva contribuem as risadas da mãe, os vestidos alegres e decotados que usava durante o jantar, só na presença da família, e a sua beleza. Para a representação de Maria, corroboram o fato de a 
mãe não se pintar nunca, ir para a reza da noite de véu de renda, comportar-se como uma verdadeira santa. Esses conflitos entre o ser e o parecer são, de certa forma, questionados pelo olhar da filha adolescente: "via tão claramente o seu modo de representar, que até sentia vergonha" (QUEIRÓS, apud MORICONI, 2001, p. 182). A mulher apresenta dois comportamentos para dois espaços: o público e o privado; duas configurações, uma de Eva, outra de Maria.

Outro discurso presente no texto é o da rivalidade entre mãe e filha, e as questões que dão origem ao conflito são: a vaidade, a atenção do pai, a presença do hóspede. A beleza da mãe é o objeto de inveja da filha: "diante daquela pulcritude minha face era uma miserável e movimentada topografia, onde eu explorava furiosamente, e em gozo físico, pequenos subterrâneos nos poros escuros e profundos, ou vulcõezinhos que estalavam entre as unhas, para o meu prazer" (QUEIRós, apud MORICONI, 2001, p. 180).

A atenção que o pai dispensa à mãe também é um dos motivos dos olhares da filha; "a risada de Mamãe era um 'muito obrigada' a meu Pai, que a adulava como se dela dependesse. Porém, ele mascarava essa adulação brincando e a tratando eternamente de menina" (QUEIRÓS, apud MORICONI, 2001, p. 181). A filha representa - não só por esses conflitos, mas também pela forma que lida com eles - a menina descobrindo-se, despertando para o desejo, embora parte dela sustente um padrão em que o feminino deve se manter passivo: "mentira: uma santa não daria aquelas risadinhas, uma santa não se divertia assim" (QUEIRÓS, apud MORICONI, 2001, p. 182). 0 despertar da sexualidade da filha acontece na percepção que ela tem da paixão que a mãe despertara no rapaz: 
beça pequenina, mostrando a sua nudez mais perturbadora - seu pescoço - naquele gorjeio trêmulo. Vi-o, ao empregado, ficar vermelho e de olhos brilhantes, para aquele esplendor branco. Papai não riu. Eu me sentia feliz e assustada (QUEIRÓS, apud MORICONI, 2001, p. 184).

Fundamentando-se na Análise do Discurso francesa, a concepção discursiva desconstrói a hipótese de transparência da linguagem, que passa a ser considerada a partir de uma opacidade constitutiva. A opacidade não resulta da má elaboração de um texto, por um emissor desqualificado como usuário da língua, mas como característica inerente à linguagem. Há, segundo essa perspectiva teórica, uma diferença fundamental sobre o que se quer dizer (as intenções do autor) e os efeitos do que se diz; uma não consonância entre os sentidos que achamos ter explicitado e os sentidos que são atribuídos pelo $\mathrm{Ou}-$ tro, o interlocutor. Assim, o sentido não é transparente, não podendo, pois, ser codificado por um emissor, que goza de plena consciência sobre os efeitos de sentido do que enuncia.

O sujeito, para a Análise do Discurso, é um sujeito descentrado, porque interpelado pelo inconsciente e pela ideologia. Esse sujeito fala a partir de sua inscrição na história e na ideologia. Assim, também, os "gestos de interpretação" se elaboram historicamente, no embate entre diferentes formulações de ordem ideológica, que orientam a produção do sentido. Conforme Orlandi (1996), formulando a partir de Pêcheux, ler não é chegar a um sentido definitivo, último, mas expor-se à opacidade do texto, "saber que o sentido sempre pode ser outro" (ORLANDI, 1996, p. 64). Nessa perspectiva, o narrador do conto "A moralista" usa dessa estratégia ao apresentar o moço que deve ser curado pela protagonista como alguém que tinha crises de angústia, que não aparecia para o jantar como o combinado e, mais tarde, apresentava-se com 
os olhos vermelhos. Essa referência ao rapaz induz o leitor a presumir que o rapaz consumia drogas. Já antes, ao comunicar a família sobre o caso que estava recebendo, a mãe anuncia: "hoje me trouxeram um caso difícil. Um rapaz viciado". A partir daí a filha o descreve sempre com os atributos afeminados, como se esse fosse o único problema do rapaz a ser resolvido pela mãe. É pela presença dos traços homossexuais, apresentados como doença, que o rapaz precisa ser tratado e não pelo consumo de drogas. Os trejeitos estavam no nível da aparência e essa precisava ser restaurada, enquanto o vício poderia ser encoberto.

0 enunciador do conto trabalha com algumas estratégias discursivas, como o silenciamento que está sendo entendido a partir do que escreve Orlandi (1993, p. 11-25), “como o não dito, visto do interior da linguagem. Não é o nada, não é o vazio sem história". Essa autora distingue silêncio fundador, aquele que existe nas palavras, que significa o não-dito e que dá espaço de recuo significante, produzindo as condições para significar; a política do silêncio que se subdivide em silêncio constitutivo, o que nos indica que, para dizer, é preciso não-dizer (uma palavra apaga, necessariamente, as "outras" palavras) e o silêncio local, que se refere à censura (aquilo que é proibido dizer em determinada conjuntura). E, como em AD o objeto de reflexão é o discurso, a autora chega a outra afirmação: "o silêncio é o real do discurso. Só se pode pensar o silêncio quando se pensa o avesso da estrutura, sem o binarismo, sem as oposições e regras escritas" (ORLANDI, 1993, p. 63). Através do que foi dito, é sempre possível se chegar ao que muitas vezes apresenta-se de forma velada no discurso, pois, ainda segundo Orlandi (1993), com ou sem palavras, o silêncio determina os processos de significação, trabalhando os limites das formações discursivas e determinando os limi- 
tes do não-dizer. Neste sentido, “a política do silêncio” representa uma linha tênue entre o que se diz e o que não se diz, ou melhor, se diz " $x$ " para não se dizer " $y$ ". A descoberta da sexualidade da filha constitui-se em um discurso velado. A atenção que a mãe despertara no rapaz inquieta a menina e ele será alvo do ciúme inconsciente da filha: "Ficou meu amigo. Sabia de modas, como ninguém. Dava opinião sobre os meus vestidos. [...] Menos tímido, ele ficara menos afeminado. [...] Em Laterra, soube depois, certas moças que por namoradeiras tinham raiva da Mamãe" (QUEIRÓS, apud MORICONI, 2001, p. 183). Outra dificuldade da filha era aceitar que a mãe tivesse um outro estatuto social que não a maternidade: "mas eu não podia pensar que minha Mãe fosse um ser predestinado, vindo ao mundo só para fazer o bem" (QUEIRÓS, apud MORICONI, 2001, p. 182). A projeção da mãe para o espaço público era motivo de insatisfação da filha. Era ela quem exigia da mãe um comportamento dentro dos modelos patriarcais, dentro de um espaço privado.

Segundo Orlandi (1993), o silêncio é exterior à linguagem, configurando-se em um estado primeiro, em torno do qual a palavra se movimenta. Nesse sentido, ele é tomado como a marca, na linguagem, da incompletude, que é fundamental no dizer, pois produz a possibilidade do múltiplo, base da polissemia. Ele é próprio a todo e qualquer processo discursivo. É na incompletude do discurso que paira a suspeita de que a moralista pudesse ser uma adúltera:

Um franco mal-estar dominava a cidade. Até que num domingo, quando Mamãe falou sobre a felicidade conjugal, sobre os deveres do casamento, algumas cabeças se voltaram quase imperceptivelmente para o rapaz, mas ainda assim eu notei a malícia. E qualquer absurdo sentimento arrasou meu coração em expectativa (QUEIRÓS, apud MORICONI, 2001, p. 183). 
No conto, ainda é possível perceber um discurso acerca do estranhamento que ocorre na sociedade quando alguém foge aos papéis sociais binários definidos: ser homem ou ser mulher. 0 culto às diferenças de hábitos e comportamentos enquadrados nos perfis masculino ou feminino é um discurso presente na sociedade e o homossexualismo, no contexto de produção do conto, é ainda apresentado como uma doença, um desvio de comportamento ou até perversão. A moralista, ao apresentar a situação do rapaz para o marido afirma: "sabe que os médicos de Santo Antônio não deram nenhum jeito?" (QUEIRÓS, apud MORICONI, 2001, p. 182). Em outra ocasião, a filha afirma que a mãe o censurava pelos gestos afeminados: "Tire a mão da cintura. Você já parece uma moça, e assim, então..." (QUEIRÓS, apud MORICONI, 2001, p. 182).

Quando a comunidade de Laterra descobriu que o rapaz trabalhava para o marido da moralista, este foi advertido: "isso não é gente para trabalhar em casa de respeito" (QUEIRÓS, apud MORICONI, 2001, p. 181). 0 uso do pronome isso já recupera, por si só, o problema da falta de identidade masculina ou feminina; ou seja, outra opção que não se encaixasse nessa dualidade era considerada, no contexto do conto, "isso": uma perversão. E para corrigir essa perversão, "Mamãe disse coisas belíssimas, a respeito da realidade do Demônio, do lado da Besta, e do lado do Anjo" (QUEIRÓS, apud MORICONI, 2001, p. 182). Na década de 50, percebem-se ainda resquícios dos discursos cientificistas que tiveram seu espaço, no Brasil, no final do século XIX e que continuavam vigorando no tempo retratado pela narrativa, meados do século XX.

As atitudes do rapaz não correspondem aos papéis sociais masculinos, instituídos culturalmente. Sua ligação com a arte e com certas atividades artesanais é apontada, no texto, como indício de sua falta de masculinidade: "sabia versos 
de cor, e às vezes os recitava baixinho"; "nas horas vagas fazia coisas bonitas para Mamãe. Pintou-lhe um leque e fez um vaso em forma de cisne, com papéis velhos molhados, e uma mistura de cola e nem sei mais o quê" (QUEIRÓS, apud MORICONI, 2001, p. 182). A menina narradora observa as atitudes do rapaz e qualquer comportamento que fuja ao padrão de masculinidade é apontado como referências ao homossexualismo. A exigência dos modelos masculinos tradicionais parte da cidade e da filha, personagens que representam o Outro nesse discurso que faz ecoar a voz da sociedade da época.

Pode-se afirmar que a representação dos papéis sociais de homens e mulheres em "A moralista" é construída e pautada pelo contexto sócio-histórico de produção do texto. Para a $\mathrm{AD}$, todo discurso é determinado por algumas condições que geralmente estão relacionadas ao contexto social em que é produzido. Nessa concepção de análise de discurso, nem os sujeitos, nem os discursos, nem os sentidos estão prontos e acabados. Segundo Orlandi (2002, p. 42-43):

O sentido não existe em si, mas é determinado pelas posições ideológicas colocadas em jogo no processo sócio-histórico em que as palavras são produzidas. As palavras mudam de sentido segundo as posições daqueles que as empregam. Elas "tiram" seu sentido dessas posições, isto é, em relação às formações ideológicas nas quais essas posições se inscrevem.

A linguagem constrói os significados sociais. Por isso, o conto de Dinah Silveira de Queirós, escrito em 1948, representa um avanço já que representa a incursão feminina pelo espaço público, porém percebe que sua atuação deve estar atrelada a um agente de controle social: a moralidade. $\mathrm{O}$ sujeito histórico, na tentativa de compreender e representar a si mesmo e ao mundo, trabalha a linguagem em sua estrutura, 
seleciona recursos para constituir-se enquanto sujeito através da interação e da interlocução com outros sujeitos. Na construção de um discurso, o sujeito trabalha a linguagem para expor seu discurso, articula a estruturação das palavras, elabora um texto composto por diversos elementos, busca produzir um sentido, explora sua subjetividade, constrói sua história. 0 conto escolhido para compor o corpus deste trabalho trata da questão da liberdade e da opressão da mulher. É, portanto, um enunciado pertencente a uma formação discursiva na qual se inclui o discurso feminino.

A complexidade da condição feminina é sempre plural. Se as mulheres formam um grupo social específico, na medida em que a diferença de gênero estrutura experiências, expectativas, constrangimentos e trajetórias sociais, isto explica a vivência feminina não ser una. Não existe só uma voz representante do discurso feminino, mas várias vozes ecoadas pela história sociocultural de cada uma dessas representadas na literatura de autoria feminina: a mãe, a menina, a moralista, a casada, a religiosa; enfim, cada uma delas, com sua ideologia, com sua formação discursiva, juntamente com seus valores, acaba produzindo um discurso que não é único, só seu, mas de todo um gênero identificável como feminino.

Dessa maneira, as formas estereotipadas no discurso da vida cotidiana respondem por um discurso social que as consolida e os preconceitos que afloram nada mais são do que exercício constante dos elementos culturais desse grupo social. 0 enunciatário, no entanto, pode oferecer obstáculos à sua realização (manutenção), provocando rupturas que vão infiltrando sensíveis mudanças iniciais, mas que podem ganhar corpo. Daí o entendimento de que todos são sujeitos da enunciação - enunciador e enunciatário -, porque o caráter interativo nada mais é do que a possibilidade de transforma- 
ção, seja pelo enunciador, seja pelo enunciatário, passando a refletir e refratar a realidade dada. É a ideia da palavra em movimento, o poder da palavra. Através dela, os sujeitos são postos em ação para reproduzir ou mudar o social.

O conto de Dinah Silveira de Queirós, "A moralista", retrata a visão que a filha tem do universo feminino, representado pelo episódio vivido pela mãe. Nesse olhar, a menina registra, no jogo das lembranças, as concepções, pontos de vistas próprios daquele espaço social e dos questionamentos de seu tempo, que sugeriam à mulher exercer certa vigilância sobre si mesma e sobre sua imagem perante a sociedade. Ainda nesse texto aparece a mudança do perfil masculino, na configuração de dois personagens, e ainda o olhar da filha para a mãe, como a filtrar o comportamento de uma mulher naquele contexto sócio-histórico. No texto em questão, a filha representa a indagação sobre sua condição feminina. Endossará ou conseguirá desvencilhar-se das amarras de uma ordem que as oprime?

\section{REFERÊNCIAS}

\section{ALTHUSSER, R. L. Ideologia e aparelhos ideológicos de} estado. Tradução de J. J. M. Ramos. Lisboa: Presença/Martins Fontes, 1974.

BAKHTIN, M. Marxismo e filosofia da linguagem. São Paulo: Hucitec, 1979.

BOSI, A. 0 conto brasileiro contemporâneo. São Paulo: Cultrix, 1994.

CÂNDIDO, A. 0 direito à literatura. In: Vários escritos. 3. ed. rev. e amp. São Paulo: Duas Cidades, 1995.

CHAUÍ, M. 0 que é ideologia. 12. ed. São Paulo, Brasiliense, 
1984. (Coleção Primeiros Passos).

FOUCAULT, M. Arqueologia do saber. 5. ed. São Paulo: Forense, 1997.

- A arqueologia do saber. Rio de Janeiro: Forense Universitária, 1969.

GOTLIB, N. B. Teoria do conto. 9. ed. São Paulo: Ática, 1998. (Série Princípios).

GREGOLIN, M. R. V. Análise do discurso: entornos do sentido. São Paulo: Cultura Acadêmica, 2001.

LAJOLO, M. Sociedade e literatura: parceria sedutora e problemática. In: ORLANDI, E. P.; LAJOLO, M.; IANNI, O. Sociedade e linguagem. Campinas: Editora da Unicamp, 1997. p. 63-86.

MAINGUENEAU, D. Novas tendências em Análise do Discurso. Campinas: Pontes, 2002.

MORICONI, Í. (Org.). Os cem melhores contos brasileiros do século. Rio de Janeiro: Objetiva, 2001. p. 180-185.

ORLANDI, E. P. Análise de discurso: princípios e procedimentos. 4. ed. São Paulo: Pontes, 2002.

. Formulação e circulação dos sentidos. Campinas: Pontes, 2001.

A Linguagem e seu funcionamento: as formas do discurso. 4. ed. Campinas, SP: Pontes, 1996.

. As formas do silêncio: no movimento dos sentidos.

2. ed. Campinas: Editora da UNICAMP, 1993. (Coleção Repertórios)

PÊCHEUX, M. Semântica e discurso: uma crítica à afirmação do óbvio. Campinas: Unicamp, 1995. 
POSSENTI, S. Discurso, estilo e subjetividade. 2. ed. São Paulo: Martins Fontes, 2001.

QUEIRÓS, D. S. de. A moralista. In: MORICONI, Í. (Org.). Os cem melhores contos brasileiros do século. Rio de Janeiro: Objetiva, 2001. p. 180-185.

ROCHA-COUTINHO, M. L. Tecendo por trás dos panos: a mulher brasileira nas relações familiares. Rio de Janeiro: Rocco, 1994.

SILVA, F. P. Vacas loucas e voadoras/o príncipe às avessas: manifestações da ironia na imprensa brasileira. In: GREGOLIN, M. do R. V. Análise do discurso: entornos do sentido. São Paulo: Cultura Acadêmica, 2001. p. 191-204.

Artigo recebido em fevereiro de 2014 e aprovado em maio de 2014.

Disponível em: http://seer.fclar.unesp.br/casa 